\title{
"IT IS THE WEED OF LOVERS" \\ THE USE OF CANNABIS AMONG TURKIC PEOPLES UP TO THE 15TH CENTURY
}

\author{
BENEDEK PÉRI \\ Department of Turkic Studies, Eötvös Loránd University \\ H-1088 Budapest, Múzeum krt. 4/D, Hungary \\ e-mail: peribenedek@gmail.com
}

Cannabis sativa $\mathrm{L}$. is one of the most popular psychoactive plants in our days. It is widely used as a medicine, a recreational drug and also as an entheogen. Archaeological findings suggest that the hemp plant was known in China as early as the 5th millennium B.C. The first written source documenting the use of cannabis as a drug is from a much later period and dates back to the 5th century B.C. The present paper offers an outline of the history of the use of cannabis as a mind altering drug among Turkic peoples from ancient times up to the late 15th century, a period of flourishing cannabis subculture both in Anatolia and in Central Asia.

Key words: entheogen, cannabis, drugs, Turkic peoples.

Intoxicating, inebriating, narcotic or visionary qualities of plants have been known to mankind from time immemorial. Some of the plants have been appreciated solely for their intoxicating effects, but others have served less mundane purposes and have much been used as medicines or entheogens.

Chewing the stimulating khat (Catha edulis) or coca (Erythroxylum coca) leaves for their invigorating effects has become an integral and inseparable part of culture in Yemen and East Africa and in the Andes respectively. ${ }^{1}$ But while khat is used mainly for recreational and social purposes, the leaves of the coca shrub occupy an important place in the indigenous medical and religious traditions of Andean cultures (Martin 1970; Gagliano 1980). With the help of coca leaves Indian shamans can more easily reach an ecstatic state where they can freely communicate with forces of the spiritual world (Martin 1970, p. 424; Pratt 2007, p. 108). Hallucinogenic plants

${ }^{1}$ For the culture of khat-chewing in Yemen and the ever spreading use of the leaves in East African countries, see Kennedy (1987); Gezon (2012); Beckerleg (2010); Carrier (2007); Gebissa (2004). On the use of coca leaves as stimulants in Andean Indian cultures, see Morales (1989, pp. $13-15)$. 
have been used in many religious traditions to facilitate an altered state of consciousness for getting a vision or ask the help of spirits for healing since prehistoric times. ${ }^{2}$

The earliest traces of the shamanistic use of peyote (Lophophora williamsii) in Northern America found at archaeological sites date back to 7000 B.C. (Pearson 2002, p. 141). Rock paintings and petroglyphs discovered in the Sahara from a somewhat earlier period suggest a flourishing cult of hallucinogenic mushrooms (Samorini 1992, pp. 69-78). Stone figures of mushrooms from the period 5th century B.C. -1 st century A.D. suggest that Ancient Mayas utilised hallucinogenic mushrooms in their religious rites as well (Sharer-Traxler 2006, pp. 750-751; Shultes-Hofmann-Rätsch 1998, p. 62). Rg-vedic hymns on soma and Avestan references to haoma clearly show that ancient Indo-Aryans used a wide range of psychoactive plants in their religious rites. ${ }^{3}$

Hemp (Cannabis sativa L.) a dioecious plant with a wide area of distribution is well known for its psychoactive qualities in many traditional cultures and religions. It is thought to have originated from Central Asia from a vast geographical area extending from the Caspian Sea to the Altai mountains, the Himalayan borderlands and North China, where it still grows wild (Vavilov 1992, pp. 108-109; Southworth 2005, p. 214). Archaeological findings suggest that hemp was cultivated in China by the 5th millennium B.C. where it became a major source for plant fibres and grains by 1000 B.C. (Zohary-Hopf-Weiss 2012, p. 107; Needham 1989, p. 171; NeedhamHuang 2000, p. 28; Li 1983, p. 31). It is not exactly known when it was applied first as a drug, but it is believed that ancient Egyptians used hemp as a medicine by 1500 B.C. (Nunn 2002, pp. 152, 195). Our first description of the visionary effects of hemp drugs is from a Chinese pharmacological work written sometime during the Han period (206 B.C. -220 A.D.) (Needham - Lu 1990, p. 150).

Neolithic pottery discovered in the steppe region of present-day Russia and Ukraine induced scholars to think that the psychoactive qualities of hemp were known to the nomadic peoples of this region as early as the 4th millennium B.C. The vessels are interpreted as braziers supposedly used for producing cannabis smoke at religious and social rituals (Sherratt 1995, p. 27; Mallory-Adams 1997, p. 92). The spread of these censers westwards towards the Carpathian Basin suggests that the mind-altering qualities of hemp smoke were known to a very wide area extending from the Yenisei to the Danube (Mallory-Adams 1997, p. 267).

Archaeological findings from Bactria lying in the southern belt of the dissemination area of hemp suggest that the pre-historic inhabitants of that region were also aware of the hallucinogenic properties of the plant and prepared "mind-altering ritualistic beverages" with cannabis by the first half of the second millennium (Merlin 2003, p. 301). As for written sources, our first data concerning the use of hemp as a psychoactive substance come from an ancient Greek historian. pp. 66-79)

${ }^{2}$ For a comprehensive list of hallucinogenic plants, see Schultes - Hofmann-Rätsch (1998, (2014). 
Herodotus (c. 484-425 BC) recorded that during the rituals following the burial of their king, Scythians used the smoke of hemp for the purposes of ceremonial purification (Asheri-Lloyd-Corcella 2007, p. 635). Historians earlier tended to doubt the veracity of this piece of information until various tools supposedly used for producing smoke for a vapour-bath and a leather pouch of hemp grains were discovered during the excavations at the Iron Age site of Pazyryk in Siberia in the late 1960s. The findings made some scholars even think that Scythians used cannabis not only for religious but for recreational purposes as well (Rudenko 1970, p. 62; Rolle 1989, p. 94).

Hemp must have been also known to nomadic Turkic tribes in their original homeland in Southern Siberia since hemp favours fertilised land that is abundantly available around stockbreeding nomadic camps (Vavilov 1992, p. 113). ${ }^{4}$ Kentir the Turkic word for 'hemp' is thought to be an Indo-European loan (Clauson 1972, p. 729). If it is so, it is not without reason to surmise that the use of hemp might have been adopted together with the transition of equestrian lifestyle of Iranian Scythian nomads by the 5 th century B.C.

It is not sure when hemp became a major crop for Turkic peoples, but by the second half of the 1st millennium A.D. it counted as an important source for grains, oil and fibres. Besides other grain crops such as millet, barley and wheat, hemp was also cultivated in the Kirghiz Khaganate (840-c. 920) (Naumov 2006, p. 40). Old Uyghur texts where the Turkish word kentir occurs first clearly show that hemp provided the inhabitants of the cities surrounding the Tarim Basin not only with bast fibres for producing fabrics but the plant was also used as an ingredient of medicines. Whether Uyghurs were aware of the plant's inherent mind-altering potentials and used any type of cannabis based drugs is not mentioned by any of our sources. Nevertheless, this possibility cannot be ruled out, as a big bunch of dried cannabis leaves was excavated from a 2700 year old tomb of a shaman in Yanghai, modern day Sinjiang (Russo et al. 2008, pp. 4172-4173). Cannabis production seems to have been continuous in the region for thousands of years and the area around the Tarim Basin remained a major cannabis producing centre in Central Asia until the 19th century. Charas, one of the drug products prepared from cannabis, was the main commodity exported from Kashghar to India during this period (Vavilov 1992; Warikoo 1995, pp. 240, 242, 243).

Nomadic Turkic peoples living in the steppe region of Central Asia might have been familiar with the custom of using intoxicating fumes like Scythians or the Massagetae before them. Though Herodotus does not say whether the Scythians used cannabis smoke for recreational purposes as well, the social use of some herbal drugs in Scythian society is attested by Cassius Maximus Tyrius, a late 2nd-century philosopher who describes a strange custom observed at some of the Scythian tribes. According to him, whenever they "are in want of the pleasure of intoxication [they] raise a

\footnotetext{
${ }^{4}$ Clauson claims the opposite and states without citing any sources that hemp is "unlikely to have been an indigenous plant in the area originally occupied by the Turks" (Clauson 1972, p. 729).
} 
pyre on which they burn odoriferous herbs. Round this pyre they sit in a circle as if it were a bowl, and feast on the smell as others do on drink; at length, becoming intoxicated with fragrance, they leap, and sing, and dance" (Taylor 1804, p. 117).

It is not without reason to suggest that not only the Scythians but other nomadic peoples were also aware of the intoxicating effect of the cannabis plant. Nevertheless, our first pieces of information connecting Turkic peoples to the use of cannabis come from the Islamic period, from the territory of historic Iran and Anatolia.

According to a widespread Islamic legend first related by al- ${ }^{\mathrm{c}}$ Uqbarī (possibly d. 690/1291) and later retold by many Muslim authors, the intoxicating effects of the hemp plant were discovered by a dervish of Turkish origin, Qutb ud-Dīn Haydar (d. approx. 1221-1223), who became the founder of an antinomian spiritual community in the late 12th century (Rosenthal 1971, pp. 49-53; Karamustafa 1994, p. 146). The ultimate source of story that is also preserved in az-Zarkashī's Zahr al- ${ }^{c}$ ariss $f i$ ahkām al-hashīsh and Maqrīzī's al-Mavāciz va' l-i'tibār bi zikr al-khitat va' l-äsārr was a member of the Haydarī community, a certain Ja far b. Muhammad ash-Shīrāzī who claimed that he had been a witness to the following extraordinary events (Rosenthal 1971, pp. 176-197; De Sacy 1826, p. 76).

Qutb ud-Dīn Haydar, as the story goes, was living in a hermitage he had founded at a remote place in the hills, in the vicinity of Nishāpūr. Though a large number of disciples gathered around him, he lived in seclusion. He often disappeared for days submerged in spiritual exercises and devotion. On an extremely hot summer day, however, the unusual heat forced him to leave the hermitage in order to breathe some fresh air. As he stood in front of the building and tried to get some relief, he noticed a plant. Unlike other shrubs and trees that stood still in the unmoving air, it was swinging and swaying to and fro as if it was dancing. He became curious and tasted it. As soon as he chewed one of its leaves, he felt a sort of unearthly bliss. He felt free from earthly concerns and he was happy as he had never been before. He shared his findings with his companions who tasted the leaves as well, and they also experienced its unusual effects. Haydar ordered them to keep this secret to themselves and instructed them to divulge it only to dervishes (fuqara $)$ who are also treading the path of spiritual quest.

The story, however fictitious it may seem, tells us a lot on how and when hemp as a hallucinogenic substance became known to the Islamic world. The legend connecting the discovery of the mind altering properties of wild hemp to Haydar makes three points clear. First, cannabis was not customarily used by Muslims before his times. Second, the introduction of this practice has something to do with the religious movement he belonged to or with the community he is said to have founded, and third, cannabis entered the Muslim cultural area from an eastern direction.

Muslim sources confirm that the use of cannabis was originally unknown in the central Islamic lands. Bāqī (1526-1600), a celebrated Ottoman poet and an acknowledged authority on religious law in the 16th century, devotes a few paragraphs in his $M e^{c}$ älim ul-Yaqin to the legal status of cannabis consumption and claims that cannabis was unknown during the time of the founders of the four major Islamic schools of jurisprudence. The custom, he adds, appeared at the end of the 7 th century after 
the Hijra, that is, somewhat later than the date suggested by the legend (Tergip 2010, p. 305).

The legal opinions Bāqī cites in his book clearly show that there were no authoritative religious texts available concerning cannabis on which a fatwa could have been based. This indicates that during the formative periods of the Islamic legal system cannabis was either not known at all in Islamic culture or its use was still not widespread. By the 15 th century the situation had considerably changed and religious authorities were forced to provide legally justifiable answers to questions pertaining to cannabis consumption. ${ }^{5}$ When Ottoman legal experts were asked to produce their views on the subject in the 16th century, they resorted to a method invented by earlier Arabic jurists by treating cannabis as one of the mind altering substances (muskirāt). In order to describe cannabis intoxication, Ottoman jurists often applied the word $s a k r$, the legal term that was also used to denote drunkenness (Tergip 2010, pp. 305306; Düzdağ 1972, pp. 144-145). Nevertheless, while Ottomans forbade the consumption of alcoholic beverages in every circumstances, hallucinogenic substances like cannabis and opium were considered permissible if they were not taken for pleasure or they did not cause intoxication (Düzdağ 1972, p. 144; İnanır 2008, p. 189). The analogy of alcohol, especially wine and cannabis intoxication coupled with Haydar's legendary role in the discovery of the plant's special properties had become heavily imprinted into Islamic public opinion by the 15th century, as a phrase al-Makrīzì uses for cannabis illustrates it quite well: "the wine of Haydar" (Rosenthal 1971, p. 154; Matthee 2005, p. 109).

Coming back to the text relating how the hallucinogenic properties of cannabis were discovered, the story seems to be a good example of etiological tales, a type of narrative that tries to explain why certain phenomena are the way they are. ${ }^{6}$ But unlike other pourqoui stories that are mere imaginary tales, this legend might have some historical truth in it.

Qutb ud-Dīn Haydar and his followers belonged to a much wider religious current generally termed Qalandarīya. Though various groups belonging to this spiritual movement might have had different symbols, they shared a common "world view" with heavy tendencies towards asceticism and antinomianism. Their system of weird looking customs and rituals, that included conscious and purposeful violation of religious prescriptions and taboos, served to free adherents from all worldly attachments. Our contemporary orthodox Muslim sources that usually speak of Qalandars in a heavily reprehensive tone, does not provide us with a systematic description of $Q a$ landari practices. Nevertheless, they seem to agree that some of these groups of ascetics not only avoided the daily five prayers and violated the rules of fasting, they also made various intoxicating preparations from cannabis (Bashir 2011, p. 177; Watenpaugh 2005, pp. 533-565).

\footnotetext{
${ }^{5}$ For a detailed analysis of the question, see Rosenthal (1971, pp. 101-120).

${ }^{6}$ On etiological narratives, see El-Shamy (1997, pp. 256-258).
} 
For what purpose did dervishes consume cannabis, contemporary authors do not state, but the following lines from a poem written by Qaygusuz Abdal (d. 1444), a 15th-century Turkish Qalandar in Anatolia, supply us with a clue.

Esrârı gördüm bugün binmiş gider bir ata

Şöyle kim derviş olmuş hergiz söylemez hatâ

Hizır donudur donu Hak'a doğrudur yönü

Şöyle cûş eyler beni erişince gizlü tâ (Gölpınarlı 1963, p. 214)

I have seen the cannabis today as it mounted a horse and rode away.

Now that he became a dervish, he never tells a lie.

Its cloak is the cloak of Khizr. It leads you to the Ultimate Turth.

It puts me into an ecstatic state of mind till I reach the Hidden Entity.

Khizr, the 'Green' one is a key personality in Islamic mystical lore. He is a friend of God, a saint who is venerated by Sufis not only for finding the water of life $(\bar{a} b-i$ hay $\bar{a} t)$ in the realm of total darkness, but more importantly for disseminating

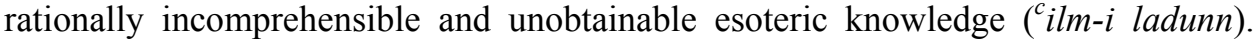
Sufi narratives often refer to him as a source for inspiration and insight and he is also mentioned in the Quran as a guide who initiated Moses into the universe of gnostic knowledge (Franke 2000, pp. 79, 60).

By placing cannabis metaphorically on an equal standing with Khizr and stating that it always tells the truth, Qaygusuz Abdal suggests that if one takes cannabis for his guide in his spiritual quest, he can surely get a glimpse of the Universal Truth.

This view might have been widespread among antinomian Qalandari groups as a blasphemous tale preserved in the Däbistān-i mazāhib, a 17th-century work written by an unknown Parsi author on the religious communities of India illustrates it very well. ${ }^{7}$

"...they relate that one day the Prophet was taking a pleasure-walk under the guidance of Jabríl, and came to a place where a great tumult was heard. Jabril said: 'This is the threshold of pleasure, enter into the house.' The Prophet consented to go in, and there he saw sitting forty persons as naked as they came from their mother, and a band busy serving; but whatever service the Prophet requested them to command him to do, they did not comply, until the time to grind bang arrived. When they had ground it, they had no cloth through which they could strain and purify it; then the Prophet, having taken his turban from his head, purified through it the juice of the bang, the colour of which remained on the turban; whence the turban of the Biní Hashem is green. When the Prophet rendered them this service, they were glad, and said among themselves: 'Let us give to this messenger of God, who is always running to the door of the ignorant, a little of the bang, that he may obtain the secrets of the Almighty power:' so they gave the remains of the juice

\footnotetext{
${ }^{7}$ On the identity of the author of the text, see Athar Ali (1999, pp. 365-373).
} 
to the Prophet. When he had drunk it, he became possessed of the secrets of the angel of destiny, and whatever men heard from him, came through the means of this bounty (Shea-Troyer 1843, pp. 222-223)."

This apocryphal and sacrilegious story comes from the traditional lore of a religious community that was characterised by the author of the Dabistān with the following words:

"It is known that there is a class among the Hindus who give themselves the term of Muselman-sofis, and really aggree in several tenets and opinions with the sufis."

Later in the text it becomes clear that the communities the anonymous writer considers Hindus are the Madārīs, the Jalālīs, subgroups of the Qalandarī movement whose customs and outward appearance reminds him of the rituals and attire of Hindu ascetics. $^{8}$

There has been a debate on the possible connection of antinomian dervish communities and Indian spiritual movements quite recently. While some scholars, like Ahmet Karamustafa, claim that the spiritual movement of deviant dervishes came into being as a protest movement and it was a natural answer to the institutionalisation of Sufism, others think that Qalandariya was born out of an interaction between groups of Muslim and Buddhist or Hindu mendicant ascetics. Yaşar Ocak suggested that Buddhist mysticism might have also contributed to the shaping of Qalandari thinking (Ocak 1992, pp. 9-10). Harriet Hartman compared the world view of Shaiva Hindu Känphatā yogis and Muslim Qalandar communities both of which, according to her, had originated in 12th-century India (Hartman 1988, pp. 111-125). Athar Abbas Rizvi took the matter one step forward when he claimed that Haydarīs adapted the custom of passing an iron rod through their male organs in order to indicate 'their determination to remain celibate' from Hindu Naga Sanyasis and aquired the practice of wearing an iron ear ring from Kānphatā yogis (Rizvi 1986, p. 307).

The possibility that Känphatā yogis might have in part influenced the evolution of the system of Haydari customs takes us back to the issue of spiritually motivated cannabis consumption. Founded by Gorakhnath in the 12th century, the Känphata school of thought belongs to Shaivite Nath Tantric traditions where cannabis and bhang, a cannabis based drink savoured by Shiva, the God of Tantra, had formed an inseparable part of religious rituals already in the 7th century (Russo 2005, p. 3). Carved wooden panels in an 18th-century Devi temple in Himachal Pradesh depicting Kānphatā yogis who are preparing bhang bear witness to this (Fisher-OhriSharma 2003, p. 50). Thus it is not without reason to suggest that we should add another item to the list of customs Haydar and his followers learnt from yogis. It is to rely on cannabis's potential to enhance the sense of divine and thus provide its user

${ }^{8}$ For a description of the customs of these religious communities, see Shea-Troyer (1843, pp. 223-230). For Madārīs and Jalālīs classified as qalandarī subgroups, see Karamustafa (1994, p. 61). 
with mystical insight and the feeling of religious ecstasy, effects that are all well known to modern consumers as well. ${ }^{9}$

We do not know much of the early life of Qutb ud-Dīn Haydar, so we cannot tell exactly where he or his followers might have met Känphatā yogis or other Shaivite Tantric communities similar to them, but according to Athar Abbas Rizvi Nath yogis started spreading from Northern India to Central Asia and Iran in the 11th century, so the place of interaction might have been somewhere in Haydar's native Khurasan as well. Our sources date the discovery of the hallucinogenic properties of cannabis to the mid-12th century. Its use as an entheogen spread from Haydarīs to other Qalandarī groups in Seljuqid Iran and Anatolia.

The Fustāt ul- ${ }^{c}$ adāla fí qavā'id us-saltana, a historical work written in Anatolia during the reign of the Seljuqids, supplies us with a fairly detailed description of the customs of a spiritual community that displayed antinomian tendencies. Muhammad b. al-Hatīb, the author of the work, does not try to hide how much he despises this group of Qalandars whom he calls chavlaqīs, "sackcloth-wearers". He gives a long list of "their detestable customs that would fill voluminous books". According to alHatīb chavlaqīs never prayed, demeaned orthodox rituals and they sneered at anyone who followed religious prescriptions. In order to offend orthodox Muslims they kept dogs, an animal that is considered ritually unclean by Islamic tradition. The desecration of sacred space was a crime they very intentionally and consciously committed by taking their dogs to masjids. We cannot tell whether it was an act meant simply to shock pious Muslims or they used Muslim sacred places for their rituals as well. Nevertheless our sources claim that these groups of dervishes prepared their cannabis based drugs, sabzak and bangāb at places of worship (Turan 1953, p. 555).

Chavlaqīs were not the only ones among Qalandari groups who consumed cannabis leaves or brewed bhang possibly in order to facilitate their spiritual quest. As we have seen before, al-Hatîb was openly hostile towards antinomian piety so it is no wonder that he reserved a few disparaging words also on Jamāl ud-Dīn Sāvī (d. 1222) whom tradition holds to be the par excellence founder of Qalandarīya as a spiritual movement. The gravest sins our author condemns Jamāl ud-Dīn for, is sodomy, or more exactly illicit relationship with a young boy and the consumption of sabzak.

The charges of sodomy and the use of cannabis as a pleasure providing drug was widely circulated in orthodox Muslim society mainly in Iran and Ottoman Turkey and became a commonplace element on the list of crimes outsiders ascribed to various Qalandarī groups. These clichés solidified into public opinion and became imprinted into people's thinking so much that they were echoed by Europeans visiting Ottoman Anatolia as well. A typical account of Torlaqs, a Turkish community of $Q a-$ landars can be read in Nicolas de Nicolay's (1517-1583) travelogue giving an account of his official visit to Constantinople in 1551 (Nicolas de Nicolay 1585, p. 105). ${ }^{10}$

\footnotetext{
${ }^{9}$ For recent research on cannabis and spirituality, see Earleywine (2002, pp. 112-113).

${ }^{10}$ Nicolas de Nicolay repeats Menavino's account who published his book in Italy two decades earlier, see Menavino (1548, pp. 81-82).
} 
"They doe also eate of the herbe called Matslach like unto the Deruis, and do sleep upon the ground, no lesse naked of shame then bare of clothes, using their damnable and abhominable sodomiticall luxurie, the one with the other more beastly and unnaturally, then would do the brute and wild beasts." 11

Nevertheless, in spite of the public opinion on cannabis consumption, the potentials inherent in the plant and the possibility to use it as a substance that might facilitate a mystic's vision of the Ultimate Reality quite naturally intrigued orthodox Sufi communities as well. Shams ud-Dīn Ahmad Aflākī, whose biographical work Manāqib ul- ${ }^{c} \bar{A}$ rifìn is one of our main sources for the life of Mavlānā Jalāl ud-Dīn Rūmī (1207-1273), relates an incident how Shams-i Tabrīzī, the saint's soul mate and spiritual guide, tried to dissuade his followers from taking to the consumption of sabzak and another cannabis based drug, hashish, claiming that cannabis induced visions are harmful (Şams al-Dīn Aḥmad al-Aflākī 1980, pp. тrr-тrr).

Mīr ${ }^{c} A$ lì-shīr Nevāyī (1441-1501) in his Eastern-Turkish paraphrase on Farīd ud-Dīn 'Attār's allegorical mystic narrative, the Conference of the Birds (Mantiq utTayr), also endeavours to prove that cannabis hinders the seeker in finding the way leading through spiritual perfection towards the Ultimate Truth. In one of the stories in his Lisān ut-Tayr a Qalandar is compared with a real Sufi master. The dervish is depicted as a drug addict, a hypocrite who is trying to deceive ordinary people. His spirituality is only a professional disguise, but in reality he is only looking for worldly gains. Due to the constant use of cannabis, he is living in an alternative reality which makes him believe that he is what he pretends to be. Nevertheless, when he challenges the spiritually advanced mystic, his worthlessness becomes evident (Nevāyī 1995, pp. 58-60).

There is another story in the book that also serves to illustrate not only the falseness and the hazards of cannabis induced experiences, but also the hypocrisy and worldliness of antinomian dervishes. A Qalandar addicted to cannabis, settles down among the ruins of an old building. Since he does not have anything else to eat but cannabis, he loses his connection with objective reality. His distorted imagination makes him believe that he is the powerful ruler of an empire who spends his time in a pleasure garden surrounded by beautiful women. He comes to himself when he is stung by a deadly scorpion and though he realises that his life was a mistake, it is too late for repentance (Nevāyī 1995, pp. 154-156).

Though cannabis has officially never entered the world of institutionalised Sufism, it had become an integral part of the life of antinomian dervish communities in Anatolia by the 14th century, as it is well attested by a story preserved in a supposedly 14th-century Turkish folk-narrative, the Hamza-nàme.

The story relates how the Muslim hero ${ }^{\mathrm{c}} \mathrm{Amr}$ captures his unbeliever opponent. Escaping from ${ }^{\mathrm{c}} \mathrm{Amr}$, Kelbād finds refuge in a Qalandarī dervish convent in Isfahān, where he becomes the disciple of the shaykh and gets addicted to cannabis. ${ }^{\mathrm{c}} \mathrm{Amr}$ fi-

${ }^{11}$ For the identification of the drug termed maslik in 16th-century Ottoman Turkish, see Péri (2012, pp. 47-66). 
nally locates him, but while Kelbād is surrounded by his fellow dervishes termed $a b d a l s$ in the story, he cannot be captured. ${ }^{\mathrm{c}} \mathrm{Amr}$ bases his stratagem on the customs of these abdals who as part of their evening rituals usually consume some cannabis together. Nevertheless, the abdals are out of stock this time so they start turning in for the night. ${ }^{c}$ Amr offers them some of his own. The abdals are rejoicing but Kelbād is suspicious of ${ }^{c}$ Amr's true identity, so he first refuses the cannabis offered to him. Nevertheless, the abdals persist and try to persuade him with the following words:

"Hey, dervish! Do you think this is how a dervish should behave? We get intoxicated and you just watch us? Our custom is that we gather and get together into an ecstatic state of mind."

Kelbād finally complies and gets intoxicated. ${ }^{\mathrm{c}} \mathrm{Amr}$ with a deftly performed trick consumes some medicine instead of cannabis and thus remains sober, and captures him in the end (Kurtcu 2006, pp. 129-130).

If the Turkish version of Hamza-name is truly from the 14th century, as Turkish scholars suggest, this text is the first Turkish text where the Turkish word generally used for cannabis and cannabis based drugs first occurs. Esrār is an Arabic loanword in Turkish, the plural of sirr, meaning 'secrets'. There are several theories offered to explain why the word took the meaning of cannabis.

Brown, the author of the first Western monograph on dervish communities, claimed that the term refers to the fact that cannabis based drugs were prepared in great secrecy (Brown 1868, p. 310). Ármin Vámbéry, a Hungarian scholar who knew the world of dervishes extremely well, because disguised as an Ottoman dervish he visited Central Asia in the 1860s, thought it otherwise and claimed that the term refers to the alternative reality of cannabis induced psychedelic visions (Vámbéry 2011, p. 121).

Surmising that antinomian dervish communities used cannabis as a Khizr like guide in their spiritual quest, in order to get initiated into the secrets of the Great Beyond, it is not without reason to suggest that dervishes might have been the first ones to use the word esrār to denote cannabis. If it is so, they greatly contributed to spreading the word that as a technical term it first entered the jargon of contemporary drug subculture and from there it was borrowed into everyday Ottoman Turkish.

Thanks to the works of major Ottoman poets of the late 15 th-early 16 th century like Hayretī (d. 1557) or Hayālī (d. 1534) who, at some point in their life treaded the dervish path themselves, the term esrär was also adopted into the vocabulary of the highly elaborate Persianate poetic language of the late 15th-early 16th century. Based on the term's double meaning and its inherent poetic potential, a whole new semantic field evolved in Ottoman classical poetry around the term esrār 'cannabis'. As deviant dervish communities that were subjected to harsh treatment and were finally forcefully integrated into the highly institutionalised Ottoman religious system during late 16th century slowly disappeared from the scene, the semantic field built up around the notion of cannabis fossilised and at the beginning of the 17th century it slowly started to fade from the common consciousness of Ottoman poets. Esrār, however, as a term for denoting cannabis not only kept its place in Ottoman vocabulary, it 
managed to survive a language reform that aimed at purging Arabic and Persian words from the language, and it is still being used in Turkish.

Esrār as the Turkish term, par excellence for cannabis, gradually superseded the earlier used beng (Persian bang) both in literary and in colloquial language sometime in the late 15 th-early 16 th century. The vocabulary change is well illustrated by 16 th17th-century European works on botany and pharmacology where the Turkish equivalent for cannabis is always given as esrār (Acosta 1585, p. 278).

Now let us return to the Anatolian Qalandar's poem we have quoted above. The poem is not an ordinary piece of Turkish poetry as it focuses on an unusual subject, the use of cannabis. Written by a poet personally involved in the Qalandari movement, it might be interpreted as a first-rate document, an eyewitness's account of trends that prevailed in early 15 th-century cannabis subculture.

As it has already been mentioned before, allusions to Khizr and the dervish who never tells a lie are references to the fact that dervish communities regarded cannabis not as an ordinary psychedelic drug, but as a source of spiritual inspiration. This notion is stressed at the end of the poem as well. In the last lines Qaygusuz tells us that cannabis is a spiritual guide for him. He feels it important, however, to add that only those can use it properly in this way who are initiated into its appropriate application.

Gel ey miskîn Kaygusuz esrârdan al öğütün

Bu âşılklar otudur yemez verme her tata (Gölpınarlı 1963, p. 214)

Come, poor Qaygusuz! Listen to the advice of the cannabis!

It is the weed of lovers (dervishes). Do not give it to an outsider! He will not

have it (in a proper way).

The last line is not the only clue in the poem that suggests that the intoxicating potentials inherent in cannabis made the plant known outside antinomian dervish circles as well. In a previous hemistich Qaygusuz ridicules a Sufi who is the symbol of religious orthodoxy in the poem for his hypocritical behaviour and materialistic thinking.

Sûfî yemez haram der gizlice de görem der

Gelen yıl çok derem der ister birazın sata

A Sufi would say, it is forbidden. He does not eat it (openly). But secretly he says, I should see (try) it.

Next year I am going to collect more and sell some of it.

The poet's claim that orthodox Sufis are not only very keen on getting intoxicated by cannabis but they also harvest and sell it implies that in the early 15th-century Anatolia cannabis was an ordinary commodity. We cannot tell when cannabis became a much sought for drug, but an Arabic hashish poem written by ${ }^{\mathrm{c}} \mathrm{Al} \overline{1} \mathrm{~b}$. Makkī suggests that it was a popular mind altering substance in the Middle East in the early 13th century (Rosenthal 1971, p. 152). References scattered in Persian and Turkish classical poems suggest that gradually bang also entered the world of Persianate elites 
of Central Asia, Iran and Anatolia and together with wine it was often served as an intoxicant at feasts. ${ }^{12}$

A short pamphlet written in Eastern Turkish sometime in the first half of the 15th century bears witness to the rising popularity of cannabis. Yūsuf Emīrī's Beng $\ddot{u}$ chägür ('Cannabis and Wine') describes a fictitious debate between the two intoxicating substances (Alpay 1972, pp. 103-125). Both Wine and Cannabis try to establish his supremacy over his rival and win the battle of words through elaborately worded argumentation supplemented with poetic quotations. Nevertheless, the debate ends in a draw which suggests that, perhaps due to its legal status, availability and cheapness, in terms of popularity cannabis had become equal to wine by the early Timurid period.

A letter written by Mehmed the Conqueror (1444-1446, 1451-1481) to the guardian cum tutor of his son Bayezid indicates how widespread cannabis consumption had become among the rich and the powerful in the Ottoman Empire by the second half of the 15 th century.

Envâ-i husûsiyetle fesâdlarından gayrî benim oğlumı tab ${ }^{c}$ - zatı muktezâsından çılkarup esrâr-ı mühmile ilkâ edüp hâtır-ı şerîfine gubâr-i hayretden inkisâr müterettüp olmış. Macâcinn-i garîbe ü dahi berş ü efyûndan mürekkep olmış niçe mükeyyifât-i ${ }^{c}$ acîbe getürüp manâfi $i^{c}-i$ kesîre $\ddot{u}$ fevâyid-i latîfe ${ }^{c}$ arz edüp dâ'ire-i insâniyetden çıkarup mizâc-i şerîfine futûr târî olmış idi. (Ferîdûn Bey 1265, p. 270) ${ }^{13}$

"Through their wicked influence and other special methods they changed my son's nature. They enticed him with secrets that cause carelessness and his noble memory became covered with the dust of bewilderment. They brought unknown electuaries, bersh and strange intoxicants prepared from opium. Claiming that these are very pleasant, useful, extremely enjoyable and helpful, they made him lose his humanity and they broke his noble character."

The letter written in 15th-century elaborately styled Ottoman prose very precisely documents the severity of young Bayezid's drug addiction. He and his friends seem to have tried most of the drugs that were available on the market. The letter explicitly states that the young men were not very picky and used "designer drugs" $\left(m a^{c} j \bar{u} n\right)$, an opium based electuary, called bersh, that was sometimes also laced with cannabis and finally opium. Two ordinary looking words in the text of the letter, however, suggest that the prince and his companions took to cannabis as well. The first lexical item is the above-mentioned esrār, the general Turkish term for cannabis, the other one is the word gubâr 'dust'.

Mehmed the Conqueror's letter is one of the first known Turkish texts that use the word gubār in the sense of cannabis. We cannot exactly tell when and where the word took this meaning, but an early 16th-century Ottoman work suggests that the

${ }^{12}$ For references, see Péri (2012, pp. 51-52, note 19).

${ }^{13}$ For the transcription of the text, see Ayverdi (1953, pp. 211-212). 
meaning 'cannabis' was attached to the word in antinomian dervish communities in Anatolia. Vāhidī’s Menākib-i Khvāje-i Jihān ve Netīje-i Jān written in 1522 describes Anatolian Abdals (abdalān-i Rüm) in the following way.

Ancak üzerlerine birer yünden örülmüs kuşak ve birer omuzlarında Ebu Müslimî nacak ve birer omuzlarında birer şecâ-i çomak, miyânlarında ikişer cür ${ }^{c}$ adân birinde hav ve çakmak ve birinde gubâr var.

$$
\text { (Akça 2008, p. 59) }
$$

"They wore only a belt woven from wool. On one of their shoulders there was a sword very similar to the one Ebu Müslim had and on the other shoulder they had a mace. There were two pouches on waist, one contained dried moss and fire-steel, the other contained cannabis."

Günāhī, an early 16th-century poet also connects the use of gubār to Qalandars who wear only a belt and live a mendicant life.

Hatt-i ser-sebzün gubârından gedâllk etmeğe

San kalenderveş kuşanmış beline yaprak gül (Âşık Çelebi 2010, p. 724)

In order to beg at least for some dust/gubār from your freshly grown facial hair, The rose has buckled a belt made from leaves like a Qalandar.

Early 16th-century poetic and prose texts supply us with ample evidence showing that by that time gubar had already left the world of dervishes and became widely used to mean cannabis both in colloquial Turkish and in the literary language.

A humorous story preserved in a 16th-century collection of anecdotes tells the tale of two friends, Haji Murad and the local müezzin, who decide to go to a bath at night, because they do not want to be disturbed by other customers. As they are walking towards their destination Haji Murad has a very scary experience. He sees that his companion suddenly grows as tall as a minaret. He gets very frightened and when he turns to his friend, the following conversation takes place between them:

„Hâci” didüm. „Ne dersin” didi. „, Gece bir mikdâr gubâr yemişidüm. Muhkem bengî olmışım gibi gözime minâre gibi görinür oldun" didüm. Güldi, eyitdi ,Be sen ne yâdgâr imişsin. Ne çok beng yemişsin."

(Ünlü 2008, pp. 226-227)

I turned to him saying, "Haji!"

"What do you want," he answered.

"Last night I took some gubār. I might have become heavily intoxicated by beng, because you look as tall as a minaret to me."

He laughed and said, "Hey, you are a funny rogue! You might have had too much beng."

It is evident from the müezzin's answer that the term beng serves as a synonym for $g u b \bar{a} r$, and the context leaves no doubt that both terms mean 'cannabis' in the story. 
Gubār, however, had an additional meaning attached to it and it was applied in Turkish texts from the 16 th century to denote 'cannabis powder'. Originally, as a technical term it might have belonged to the register of cannabis subculture and it might have been used only in cases when it was deemed important to differentiate between the types of drugs prepared from cannabis. In other contextual situations the general word, esrār was used. This situation is reflected by 16th-century European travellers' accounts where esrār means 'cannabis powder' as well. Giovanni Antonio Menavino, an Italian who spent some years in Ottoman captivity, describes a dervish ritual that involved the consumption of cannabis powder he calls esrār in his book published in 1548 (Menavino 1548, pp. 78-79). ${ }^{14}$ Hans Dernschwam informs his readers that Turks eat esrār, a powder prepared from the dried leafs of wild hemp (Babinger 1923, p. 54).

It has been mentioned above that as a technical term taken from the jargon of 15th-16th-century Ottoman cannabis subculture, gubār became part of the semantic field that developed around 'cannabis' (esrār) in Ottoman poetry and often occurred together with words like esrār 'cannabis' or khayrān 'cannabis induced intoxication'. Persian poets had used the word gubār in a double sense earlier, meaning 'dust' and a type of script, a very fine and minuscule version of nesih (Schimmel 1992, p. 241). ${ }^{15}$ The additional meaning 'cannabis' greatly enhanced the poetic potential of the word which Ottoman poets tried to exploit completely, and they strived to create poetic contexts where all three meanings could be presented either explicitly or in the form of an allusion as $\mathrm{Me}^{\mathrm{c}} \overline{\mathrm{a}} \mathrm{l} \overline{1}$ and Merdümī did in the early 16 th century.

$\mathrm{Me}^{\mathrm{c}} \overline{\mathrm{a}} \mathrm{i}$ :

Beni bu hatt-i gubârun eyledi hayrân dedüm

Dedi kim lâ büd gubârun bu durur hâsiyeti (Ambros 1982, p. 306)

I said, "Your gubārī type of handwriting made me dumbfounded." /I said,

"The dust of your facial hair made me dumbfounded".

He/She said, "Well, this is the nature of cannabis (gubār)."

Merdümī:

Hayret alur ${ }^{c}$ aklumı görsem gubâr-ı hattunı

Vâkıf-l esrâr-l c lşkun vâlih ü hayrân olur (Edirneli Nazmî 2012, p. 764)

Bewilderment takes hold of my mind as soon as I see the dust of your facial hair/I see the gubār script of your letter,

All those who get to know the secrets/cannabis of your love become stunned and dumbfounded.

The increasing instances of references to cannabis and its use in Ottoman historical and literary sources in the 16th century clearly indicate how popular cannabis got in late 15 th-early 16th-century Ottoman society. Earlier it was a substance used

\footnotetext{
${ }^{14}$ Menavino's description was repeated by other European authors: Sanovino (1568, p. 31); Lonicer (1584, p. 110); Bandier (1625, p. 186).

${ }^{15}$ On gubār or gubārī script, see Schimmel (1970, p. 7); Derman (1998, p. 15). 
strictly for spiritual purposes, as an entheogen in antinomian dervish communities and by the 16 th century it became a widely circulated popular psychedelic drug with a highly developed subculture. Besides being consumed in its most basic form as beng or esrār , it was also used in a pulverised version as gubār and it became the main ingredient of many "designer drugs" generally termed $m a^{c} j \bar{u} n$. Nevertheless, this part of the cannabis's career among the Turkic peoples is another story.

\section{Bibliography}

Acosta, Cristoval (1585): Trattato della historia, natura et virtua delle droghe medicinali et altri semplici rarissimi che vengono portati delle India Orientali in Europa. Venezia.

Akça, V. (2008): Menâkıb-ı H`âce-i Cihân ve Netice-i Cân. Yüksek Lisans Tezi. Sivas.

Alpay, G. (1972): Yusuf Emiri'nin Beng ü Çagır Adlı Münazarası. In: Türk Dili Araştırmaları Ylllı̆̆ -Belleten. Nadirkitap, pp. 103-125.

Ambros, E. (1982): Candid Penstrokes. The Lyrics of Me'âlî, an Ottoman Poet of the 16th Century. Berlin.

Asheri, David-Lloyd, Alan-Corcella, Aldo (2007): Commentary on Herodotus Books I-IV. Edited by Oswyn Murray \& Alfonso Moreno. Oxford.

Âşık Çelebi (2010): Meşấ $\hat{a}^{c} u ̈$ 'ş-Suc arâ. Vol. 2. Hazırlayan Filiz Kılıç. İstanbul.

Athar Ali, M. (1999): The Elusive Seeker of Universal Truth: The Identity and Environment of the Author of the "Dabistān-i Mazāhib". JRAS Third series Vol. 9, No. 3, pp. 365-373.

Ayverdi, S. (1953): Edebî ve Manevî Dünyası İçinde Fatih. İstanbul.

Babinger, F. (1923): Hans Dernschwam's Tagebuch einer Reise nach Konstantinopel und Kleinasien (1553/55). München.

Bandier, M. (1625): Histoire générale de la religion des Turcs. Paris.

Bashir, Sh. (2011): Sufi Bodies: Religion and Society in Medieval Islam. New York.

Beckerleg, S. (2010): Ethnic Identity and Development. Khat and Social Change in Africa. New York.

Brown, J. P. (1868): Dervishes or Oriental Spiritualism. London.

Carrier, N. C. (2007): Kenyan Khat: The Social Life of a Stimulant. Leiden.

Clauson, G. (1972): An Etymological Dictionary of Pre-Thirteenth-Century Turkish. Oxford.

Dalechamps, Jacques (1586): Historia generalis plantarum. II. Lyon.

Derman, U. (1998): Letters in Gold. Ottoman Calligraphy from the Saklp Sabancı Collection, İstanbul. New York.

De Sacy, S. (1826): Chrestomathie Arabe. I. Paris.

Düzdağ, M. E. (1972): Şeyhülislâm Ebusuud Efendi Fetvaları Işı̆̆ında 16. Yüzyıl Türk Hayatı. İstanbul.

Earleywine, M. (2002): Understanding Marijuana. A New Look at the Scientific Evidence. Oxford.

Edirneli Nazmî (2012): Mecma $a^{c}$ 'n-Nezâ 'ir. Hazırlayan Fatih M. Köksal. Ankara.

$=$ http://ekitap.kulturturizm.gov.tr/Eklenti/10721,edirneli-nazmimecmaun-nezairpdf.pdf?0 (Accessed 16 March 2014).

El-Shamy, H. (1997): Etiological Narratives. In: Green, T. A. (ed.): Folklore: An Encyclopaedia of Beliefs, Customs, Tales, Music, and Art. Santa Barbara, pp. 256-258.

Ferîdûn Bey (1265): Mecmû́c a-i münşe'ât us-selâtîn. Vol. 1. İstanbul.

Fisher, E. -Ohri, V. Ch. - Sharma, V. (2003): The Temple of Devi-Kothi: Wall Paintings and Wooden Reliefs in a Himalayan Shrine of the Great Godess in the Churah Region of the Chamba District, Himachal Pradesh. Zurich. 
Franke, Patrick (2000): Begegnung mit Khidr. Beirut.

Gagliano, J. A. (1980): Coca and Popular Medicine in Peru: An Historical Analysis of Attitudes. In: Browman, D. L. - Schwartz R. A. (eds): Spirits, Shamans and Stars: Perspectives from South America. The Hague, pp. 39-54.

Gebissa, E. (2004): Leaf of Allah: Khat and Agricultural Transformation in Harerge, Ethiopia 1875-1991. Oxford.

Gezon, L. (2012): Drug Effects: Khat in Biocultural and Socioeconomic Perspective. Walnut Creek CA.

Gölpınarlı, A. (1963): Alevî-Bektâşî Nefesleri. İstanbul.

Hartman, H. (1988): Can a Hindu Utopia Be a Muslim Utopia? Examples from 12th Century India and Beyond. International Journal of Comparative Sociology Vol. 29, pp. 111-125.

İnanır, A. (2008): Ibn Kemal'ın Fetvaları Işığında Osmanlı'da İslam Hukuku. Doktora Tezi. İstanbul, İstanbul Üniversitesi.

Karamustafa, A. T. (1994): God's Unruly Friends: Dervish Groups in the Islamic Later Middle Period, 1200-1500. Salt Lake City.

Kennedy, J. G. (1987): The Flower of Paradise. The Institutionalized Use of the Drug Qat in North Yemen. Dordrecht.

Kurtcu, N. (2006): Hamza-nâme (16. cilt). Hamza-nâme Kahramanlarının Türk Destan Edebiyatındaki Yeri. Yüksek Lisans Tezi. Çanakkale, Onsekiz Mart Üniversitesi.

Li, H. (1983): The Domestication of Plants in China: Ecogeogphical Considerations. In: Keightley, D. N. (ed.): The Origins of Chinese Civilization. Berkeley, pp. 21-63.

Lonicer, Ph. (1584): Chronicorum Turcicorum. Tomus primus et secundus. Frankfurt.

Mallory, J. P. - Adams, D. Q. (1997): Encyclopaedia of Indo-European Culture. London.

Martin, R. (1970): The Role of Coca in the History, Religion and Medicine of South American Indians. Economic Botany Vol. 24, pp. 422-438.

Matthee, R. P. (2005): The Pursuit of Pleasure: Drugs and Stimulants in Iranian History, 15001900. Princeton.

Menavino, G. A. (1548): Trattato de costumi et vita de Turchi. Firenze.

Merlin, M. D. (2003): Archeological Evidence for the Tradition of Psychoactive Plant Use in the Old World. Economic Botany Vol. 57, No. 3, pp. 295-303.

Morales, E. (1989): Cocaine: White Gold Rush in Peru. Phoenix AZ.

Naumov, I. V. (2006): The History of Siberia. Abingdon.

Needham, J. (1989): Science and Civilization in China. Vol. 6/1. Botany. Cambridge.

Needham, J. - Huang H. T. (2000): Science and Civilization in China. Vol. 6/5. Fermentations and Food Science. Cambridge.

Needham, J.-Lu, Gwei-djen (1990): Science and Civilization in China. Vol. 5/2. Spagyrical Discovery and Invention: Magisteries of Gold and Immortality. Cambridge.

Nevāyī, Ali Şir (1995): Lisānü 't-Tayr. Hazırlayan Mustafa Canpolat. Ankara.

Nicolas de Nicolay (1585): The Nauigations, Peregrinations and Voyages, Made into Turkie. London. (https://www.youtube.com/watch?v=9iRftQ9HYMg)

Nunn, J. F. (2002): Ancient Egyptian Medicine. Norman.

Ocak, Y. (1992): Osmanlı İmparatorluğunda Marjinal Sûfîlik: Kalenderîler (XIV-XVII. Yüzyıllar). Ankara.

Pearson, J. L. (2002): Shamanism and the Ancient Mind: A Cognitive Approach to Anthropology. Walnut Creek.

Péri, B. (2012): Beng, eszrár, maszlag: a cannabis és a cannabis tartalmú drogok az anatóliai törökségnél [Beng, esrar, maslik: cannabis, cannabis based drugs and the Turks in Anatolia. A terminological overview]. Keletkutatás 2012/tavasz, pp. 47-66. 
Pratt, Ch. (2007): An Encyclopaedia of Shamanism. Vol. 1. New York.

Rizvi, S. A. A. (1986): A History of Sufism in India. Vol. 1. New Delhi.

Rolle, R. (1989): The World of the Scythians. Berkeley.

Rosenthal, F. (1971): The Herb. Hashish Versus Muslim Society. Leiden.

Rudenko, S. I. (1970): Frozen Tombs of Siberia: the Pazyryk Burials of Iron Age Horsemen. Berkeley.

Russo, E. (2005): Cannabis in India: Ancient Lore and Modern Medicine. In: Mechoulam, R. (ed.): Cannabinoids as Therapeutics. Basel-Boston-Berlin.

Russo, E. B. et al. (2008): Phytocemical and Genetic Analyses of Ancient Cannabis from Central Asia. Journal of Experimental Botany 59, pp. 4172-4173.

Samorini, G. (1992): The Oldest Representations of Hallucinogenic Mushrooms in the World (Sahara Desert, 9000-7000 B.P.). Integration Vol. 2, No. 3, pp. 69-78. = http://www.samorini. it/doc1/sam/sah_int.htm (Accessed 5 January, 2014).

Şams al-Dīn Aḥmad al-Aflākī (1980): Manākib al- ${ }^{c} \bar{A}$ rifïn. Yayınlayan Tahsin Yazıcı. Ankara.

Sanovino, F. (1568): Historia dell'origine et imperio de Turchi. Venezia.

Schimmel, A. (1970): Islamic Calligraphy. Leiden.

Schimmel, A. (1992): A Two-Colored Brocade. The Imagery of Persian Poetry. Chapel Hill \& London.

Schultes, R. E.-Hofmann, A.-Rätsch, Ch. (1998): Plants of the Gods. Their Sacred, Healing and Hallucinogenic Powers. Rochester.

Sharer, R. J. - Traxler, L. P. (2006): The Ancient Maya. Stanford.

Shea, D.-Troyer, A. (1843): The Dabistán, or School of Manners, Translated from the Original Persian with Notes and Illustrations. Vol. 2. Paris.

Sherratt, A. (1995): Alcohol and Its Alternatives: Symbol and Substance in Pre-Industrial Cultures. In: Goodman, J. - Lovejoy, E. - Sherratt, A. (eds): Consuming Habits. Drugs in History and Anthropology. London-New York, pp. 11-46.

Southworth, F. C. (2005): Linguistic Archeology of South Asia. Abingdon-New York.

Taillieu, D. (2014): Haoma I. Botany. In: Encyclopaedia Iranica online edition: http://www.iranica online.org/articles/haoma-i (Accessed 6 January 2014).

Taylor, T. (1804): The Dissertations of Maximus Tyrius. London.

Tergip, A. (2010): Bâkî'nin Me'âlimü'l-Yakîn Adlı Eseri Üzerinde Dil Incelemesi. (Metin-Sözlük.) Yüksek Lisans Tezi. İstanbul, İstanbul Üniversitesi.

Turan, O. (1953): Selçuk Türkiyesi Din Tarihine Dair Bir Kaynak: Fusțāt ul- ${ }^{c}$ adāle fì kavā $\bar{a}^{c}$ issaltana. In: 60. Doğum Yll Münasebetiyle Fuad Köprülü Armağant. Mélanges Fuad Köprülü. İstanbul, pp. 531-564. (http://www.ttk.gov.tr/index.php?Page=Yayinlar\&Kitap No=909; http://www.worldcat.org/title/60-dogum-yl-munasebetiyle-fuad-koprulu-armagan-melangesfuad-koprulu/oclc/24276342).

Ünlü, O. (2008): Cinânî’nin Bedâyiü'l-Âsârı. Doktora Tezi. İzmir, Ege Üniversitesi.

Vámbéry, Á. (2011): Keleti életképek [Eastern mosaics]. Dunaszerdahely.

Vavilov, N. I. (1992): Origin and Geography of Cultivated Plants. Cambridge.

Warikoo, K. (1995): Gateway to Central Asia. The Transhimalayan Trade of Ladakh, 1846-1947. In: Osmaston, H. A. - Denwood, P. (eds): Recent Research on Ladakh 4 \& 5: Proceedings of the Fourth and Fifth International Colloquia on Ladakh. Delhi, pp. 235-243.

Watenpaugh, H. Z. (2005): Deviant Dervishes: Space, Gender and the Construction of Antinomian Piety in Ottoman Aleppo. Journal of Middle East Studies Vol. 37, pp. 533-565.

Zohary, D.-Hopf, M.-Weiss, E. (2012): Domestication of Plants in the Old World. Oxford, 4th edition. 
